\title{
PENGEMBANGAN FASILITAS DAN UTILITAS STASIUN BUMIAYU GUNA MENINGKATKAN PELAYANAN TERHADAP PENUMPANG
}

\author{
Rizky Farezi Mony ${ }^{1}$, email : rizkyfarezi.mony@ptdisttd.ac.id \\ Muhardjito $^{2}$, email : muhardjito@gmail.com \\ I Made Suraharta ${ }^{3}$, email : isuraharta@ptdisttd.ac.id \\ ${ }^{1,2,3}$ Program Studi Manajemen Transportasi Perkeretaapian \\ Politeknik Transportasi Darat Indonesia - STTD ${ }^{1,2,3}$
}

\begin{abstract}
ABSTRAK
Tujuan dari penelitian ini adalah mengetahui kondisi fasilitas yang ada pada stasiun Bumiayu, mengetahui faktor yang menjadi prioritas utama dari pelayanan pada fasilitas dan utilitas Stasiun Bumiayu untuk ditingkatkan kualitas pelayanannya. Oleh karena itu perlu direncanakan pengembangan Stasiun Bumiayu berdasarkan hasil analisis tingkat kepuasan penumpang. Penelitian ini difokuskan untuk mengembangkan fasilitas dan utilitas yang ada pada stasiun Bumiayu dan disesuaikan dengan Standar Pelayanan Minimum (SPM) PM No. 63 Tahun 2019. Fasilitas yang dikembangkan, antara lain : peron, kanopi (overcapping), lahan parkir, dan ruang tunggu. Metode yang dilakukan untuk mengevaluasi tingkat pelayanan stasiun setelah dan sebelum pembangunan pengumpulan data dilakukan melalui survei kemudian data terkumpul dianalisis dengan metode IPA (Importance Performance Analysis). Hasil analisis Costumer Statisfaction Index menunjukkan bahwa penumpang di Stasiun Bumiayu pada saat ini merasa CUKUP PUAS terhadap pelayanan yang diberikan dengan nilai 0,54. Dengan bertambahnya jumlah penduduk di Stasiun Bumiayu tiap tahunnya belum tentu tahun berikutnya penumpang akan merasa cukup puas dengan kinerja pelayanan penumpang di Stasiun Bumiayu.
\end{abstract}

Kata Kunci: pengembangan fasilitas, utilitas stasiun bumiayu, peningkatan pelayanan, penumpang.

\section{ABSTRACT}

The purpose of this study is to determine the condition of existing facilities at Bumiayu Station, to determine the factors that are the top priority of services at Bumiayu Station facilities and utilities to improve service quality. as well as planning the development of Bumiayu Station based on the results of an analysis of passenger satisfaction levels. This research is focused on developing existing facilities and utilities at Bumiayu station, and adjusted to the Minimum Service Standards (SPM) PM No. 63 of 2019. The facilities developed include: platforms, canopies (overcapping), parking lots and waiting rooms. And evaluating the service level of the station after and before the construction of data collection is carried out through a survey then the collected data is analyzed using the IPA (Importance Performance Analysis) method. The results of the Customer Statisfaction Index analysis show that passengers at Bumiayu Station at this time feel SATISFIED with the services provided with a value of 0.54. With the increase in the number of residents at Bumiayu Station each year, it is not certain that the following year passengers will be satisfied enough with the performance of passenger service at Bumiayu Station..

Keywords: development of facilities, utilities of Bumiayu station, improving services, passengers

\section{PENDAHULUAN}

Kereta api adalah bentuk transportasi rel yang terdiri dari serangkaian kendaraan yang ditarik sepanjang jalur kereta api untuk mengangkut kargo atau penumpang. Gaya gerak disediakan oleh lokomotif yang terpisah atau motor individu dalam beberapa unit. Sumber energi lain termasuk kuda, tali atau kawat, gravitasi, pneumatik, baterai, dan turbin gas. Rel kereta api biasanya terdiri dari dua, tiga atau empat rel, dengan sejumlah monorel dan guideways maglev dalam campuran.

Kereta api merupakan salah satu moda transportasi yang memiliki karakteristik dan keunggulan khusus terutama dalam kemampuan mengangkut, baik penumpang maupun barang secara masal, hemat energi, hemat dalam penggunaan ruang, mempunyai faktor keamanan yang tinggi dan 
tingkat pencemaran yang rendah serta lebih efisien dibanding moda transportasi lainnya.

Menyadari akan keunggulan dan karakteristik dari kereta api, maka peran perkeretaapian perlu lebih ditingkatkan dalam upaya pengembangan sistem transportasi nasional secara terpadu, hal itu diikuti dengan penyelenggaraan perkeretaapian yang dimulai dari perencanaan, pembangunan, perawatan, dan pengoperasian yang baik. Untuk meningkatkan pelayanan pengguna jasa salah satunya yaitu di stasiun, karena stasiun merupakan point of transhipment dimana stasiun merupakan titik simpul dalam penyelenggaraan perkeretaapian. Menurut UU No.23 tahun 2007 tentang Perkeretaapian Serta PP No.56 tentang Penyelenggaraan Perkeretaapian. Definisi stasiun kereta api adalah tempat pemberangkatan dan pemberhentian kereta api untuk melayani naik dan turunnya penumpang dan bongkar muat barang dan atau untuk keperluan operasional kereta api. Stasiun kereta api juga dapat didefinisikan sebagai pusat pengaturan perjalanan kereta api, tanpa persetujuan stasiun kereta api tidak dapat berjalan, dengan kata lain stasiun digunakan sebagai transportasi.

Stasiun Bumiayu merupakan salah satu stasiun DAOP 5 Purwokerto yang termasuk ke dalam stasiun kelas II atau sedang. Stasiun Bumiayu berada di pusat Kecamatan Bumiayu yang berjarak 200 m sebelah barat dari Jalan Raya Nasional. Di sebelah selatan Stasiun Bumiayu terdapat Pasar Talok yang merupakan pusat perdaganan, sehingga banyak diantara penumpang kereta api adalah seorang pedagang dari berbagai daerah. Stasiun Bumiayu melayani naik dan turun penumpang, maka harus mampu memberikan pelayanan yang maksimum terhadap pengguna jasa kereta api. Berdasarkan hasil survey inventarisasi di lapangan, serta data sekunder yang telah diperoleh, masih ditemukannya kekurangan terhadap fasilitas stasiun, sehingga berdampak pada tingkat kepuasan pelayanan terhadap pengguna jasa kereta api. Hal ini menunjukkan bahwa belum dipenuhinya standar pelayanan minimum (SPM) angkutan penumpang di Stasiun yang didasarkan pada PM No. 63 Tahun 2019, sehingga dapat memberikan pelayanan terbaik kepada pengguna jasa kereta api. Maka dari itu perlu dilakukan penelitian untuk mengetahui kualitas pelayanan dari penyelenggara jasa sebagai dasar untuk meningkatkan mutu pelayanan yang diterima pengguna jasa kereta api. Untuk itu penulis mengambil penelitian tentang pengembangan fasilitas dan utilitas stasiun bumiayu guna meningkatkan pelayan terhadap penumpang.

\section{METODOLOGI PENELITIAN}

Penelitian ini dilakukan dengan beberapa tahapan diantaranya :

\section{Pengumpulan data melalui survey}

Pengumpulan data dilakukan melalui wawancara terhadap penumpang dan pengguna di stasiun. Survei wawancara penumpang, dilakukan dengan wawancara langsung atau menggunakan kuisioner. Dalam survei ini memungkinkan pengumpulan informasi yang maksimum dalam hal kebiasaan perjalanan yang dilakukan oleh penumpang, karakteristik penumpang meliputi pilihan moda, tujjan perjalanan, serta pelayanan yang diharapkan terhadap penyedia jasa transportasi khususnya kereta api

\section{Analisis data hasil survey}

Data terkumpul selanjutnya akan dilakukan analisis dengan menggunakan metode IPA (Importance Performance Analysis). Metode IPA digunakan untuk mendapatkan infromasi tentang tingkat kepuasan pelanggan terhadap suatu pelayanan dengan cara mengukur tingkat kepentingan dan tingkat pelaksanaannya. Tingkat kepentingan dari kualitas pelayanan adalah seberapa penting suatu pelayanan bagi pelanggan terhadap kinerka pelayanan. Skala Likert 5 tingkat digunakan untuk mengukur tingkat kepentingan yang sangat penting, penting, cukup penting, kurang penting dan tidak penting

\section{HASIL DAN DISKUSI}

3.1 Analisis Karakteristik Penumpang Analisis karakteristik penumpang dilakukan dengan melihat beberapa aspek diantaranya

1. Jenis kelamin

2. Pekerjaan

3. Tingkat pelayanan di stasiun

4. Pendapat Tentang Pengembangan Stasiun

5. Fasilitas Yang Ingin dikembangkan

6. Usia

7. Maksud Perjalanan Penumpang

8. Moda yang digunakan

9. Kota Tujuan Penumpang

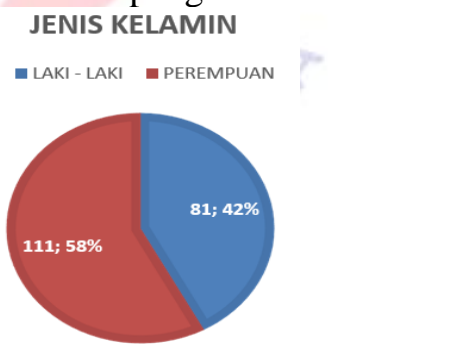

Gambar 1 data jenis kelamin 


\section{PEKERJAAN PENUMPANG}

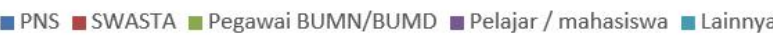

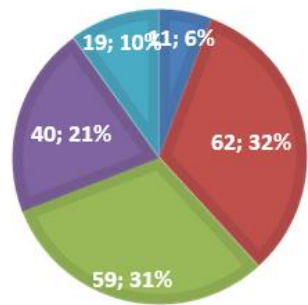

Gambar 2 data pekerjaan penumpang

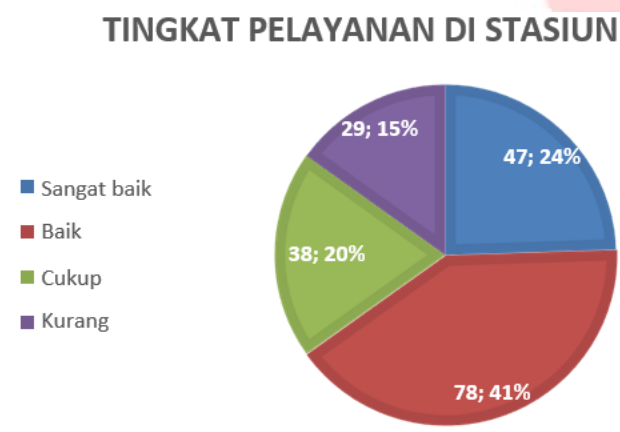

Gambar 3 tingkat pelayanan di stasiun

- Setuju

- Tidak Setuju

- Tidak tahu

\section{PERSETUJUAN TENTANG}

PENGEMBANGAN STASIUN

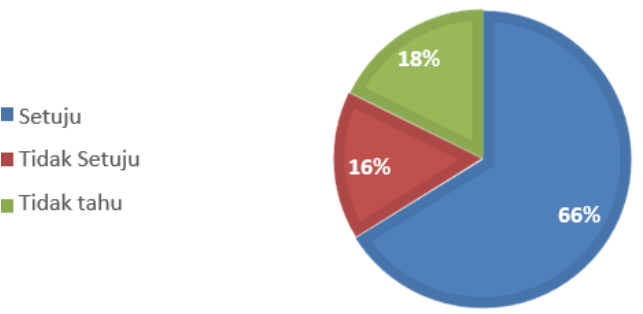

Gambar 4 persetujuan tentang pengembangan stasiun

\section{FASILITAS YANG INGIN DIKEMBANGKAN}

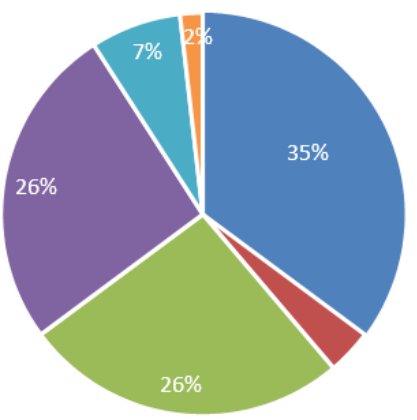

- Perluasan lahan parkir

- Perluasan ruang tunggu

Eeninggian peron

- Penambahan atap pada jalur peron (over caping)

— Fasilitas untuk disabilitas

ש Lainnya
USIA

- $<20$ TAHUN

- 21 - 30 TAHUN

- 31 - 40 TAHUN

घ $>40$ TAHUN

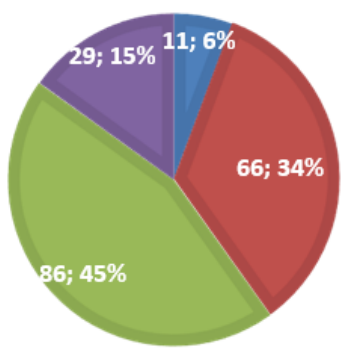

Gambar 6 data usia penumpang

\section{MAKSUD PERJALANAN}

- Bekerja

- Sekolah / Kuliah

Rekreasi / Wisata

- Lainnya

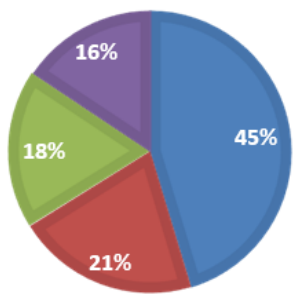

Gambar 7 data maksud perjalanan

MODA YANG DIGUNAKAN UNTUK KE STASIUN

- Sepeda = Sepeda Motor = Mobil = Angkutan Umum = Jalan Kaki = Lainnya

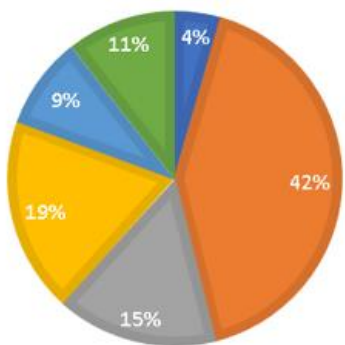

Gambar 8 data moda yang digunakan untuk menuju ke stasiun

\section{Kota Tujuan Penumpang}

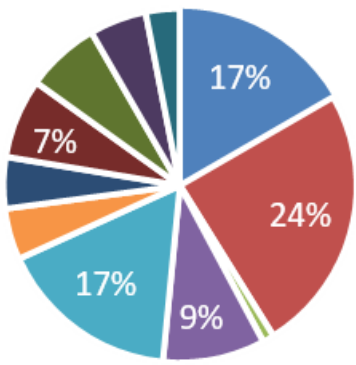

- Yogyakarta

- Purwokerto

Madiun

- Semarang

- Jakarta

Kebumen

Gambar 5 data fasilitas yang ingin dikembangkan

Gambar 9 kota tujuan penumpang 


\subsection{Analisis Tingkat Kepuasan}

Metode yang digunakan dalam menganalisis tingkat kepuasan pengguna stasiun pada penelitian ini adalah metode IPA (importance performance analysis). Dalam metode ini pertama harus dihitung nilai rata-rata tingkat kepuasan atau kinerja dari masing-masing atribut penilaian. Nilai ini berfungsi sebagai dasar dalam pemetaan masing-masing atribut ke dalam diagram kartesius. Kemudian dihitung skor rata-rata dari tingkat kepentingan dan kinerjanya

Tabel 1 Rata-rata Tingkat Kepentingan dan Kinerja

\begin{tabular}{|c|c|c|c|}
\hline No & Pernyataan & $\begin{array}{c}\text { Kepentingan } \\
\text { (Y) }\end{array}$ & $\begin{array}{c}\text { Kepuasan } \\
\text { (X) }\end{array}$ \\
\hline 1 & F1 & 3,96 & 2,39 \\
\hline 2 & F2 & 4,56 & 3,20 \\
\hline 3 & F3 & 4,53 & 2,40 \\
\hline 4 & F4 & 3,97 & 2,63 \\
\hline 5 & F5 & 4,34 & 3,11 \\
\hline 6 & F6 & 4,47 & 1,70 \\
\hline 7 & F7 & 4,18 & 2,92 \\
\hline 8 & F8 & 2,51 & 2,32 \\
\hline 9 & F9 & 4,42 & 2,94 \\
\hline 10 & F10 & 4,49 & 3,91 \\
\hline 11 & F11 & 4,53 & 2,81 \\
\hline 12 & F12 & 4,69 & 1,64 \\
\hline
\end{tabular}

\begin{tabular}{|c|l|}
\hline No & \multicolumn{1}{|c|}{ Indikator Pelayanan } \\
\hline F1 & Akses menuju stasiun \\
\hline F2 & Ketersediaan informasi di stasiun \\
\hline F3 & Aksesibilitas naik turun penumpang \\
\hline F4 & Keramahan dan kesopanan petugas \\
\hline F5 & Kecepatan dalam memberikan informasi \\
\hline F6 & Fasilitas pelayanan penumpang \\
\hline F7 & Adanya fasiltas penyandang cacat \\
\hline F8 & Adanya ruang ibu menyusui \\
\hline F9 & Adanya toilet \\
\hline F10 & Adanya tempat ibadah \\
\hline F11 & Ketersediaan petugas untuk melayani \\
\hline F12 & Ketersediaan lahan parkir \\
\hline
\end{tabular}

Dari data tabel di atas, data akan diolah dan dipetakan ke dalam diagram kartesius yang disajikan dalam bentuk gambar. Sumbu X merupakan nilai rataan kinerja dan sumbu Y merupakan rataan kepentingan. Untuk mengetahui secara jelas penempatan dari 12 atribut kualitas jasa yang telah dianalisa tersebut, maka 12 atribut tersebut akan dikelompokkan menjadi empat kuadran

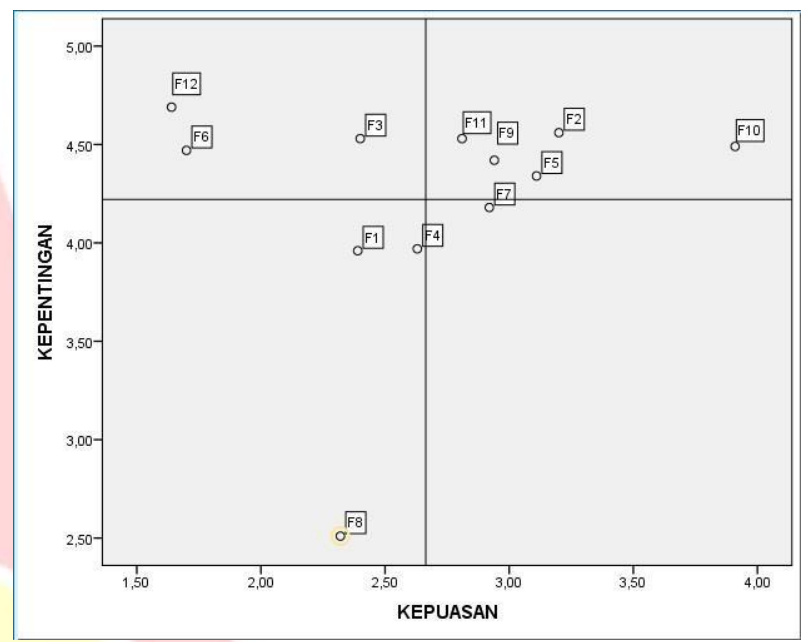

Gambar 10 diagram kartesius 4 kuadran kepuasan vs kepentingan

4 kuadran tersebut mencakup :

a. Kuadran I (Prioritas Utama)

b. Kuadran II (Pertahankan prestasi)

c. Kuadran III (Prioritas Rendah)

d. Kuadran IV (Berlebihan)

Untuk mengetahui tingkat kepuasan penumpang dapat dilakukan dengan menggunakan pengukuran Costumer Statisfaction Index (CSI). Untuk menghitung CSI diperlukan rata-rata tingkat kepentingan dan kinerja dari masing-masing atribut penilaian. CSI digunakan untuk dijadikan acuan dalam menentukan sasaran - sasaran dimasa yang akan datang. Hasil perhitungan dari Costumer Statisfaction Index dapat dilihat pada tabel dibawah ini

Tabel 2 Kategori kepuasan CSI

\begin{tabular}{|c|c|}
\hline Nilai & Kategori \\
\hline $0,00-0,34$ & Tidak Puas \\
\hline $0,35-0,50$ & Kurang Puas \\
\hline $0,51-0,65$ & Cukup puas \\
\hline $0,66-0,80$ & Puas \\
\hline $0,81-1,00$ & Sangat Puas \\
\hline
\end{tabular}

Dari perhitungan menggunakanmetode Costumer Statisfaction Index (CSI) didapatkan nilai atau tingkat kepuasan penumpang terhadap pelayanan di Stasiun Bumiayu sebesar 0,54. Pada perolehan hasil perhitungan ini maka dapat disimpulkan bahwa pengguna jasa "Cukup Puas" dengan pelayanan yang ada di Stasiun Bumiayu 
Tabel 3 Hasil Perhitungan Customer Statisfication Index (CSI)

\begin{tabular}{|c|c|c|c|c|c|}
\hline No & Pernyataan & Kepentingan $(\mathrm{Y})$ & Kepuasan $(\mathrm{X})$ & Weighted Factor & Weighted Score \\
\hline 1 & F1 & 3,96 & 2,39 & 0,08 & 0,19 \\
\hline 2 & F2 & 4,56 & 3,20 & 0,09 & 0,29 \\
\hline 3 & F3 & 4,53 & 2,40 & 0,09 & 0,21 \\
\hline 4 & F4 & 3,97 & 2,63 & 0,08 & 0,21 \\
\hline 5 & F5 & 4,34 & 3,11 & 0,09 & 0,27 \\
\hline 6 & F6 & 4,47 & 1,70 & 0,09 & 0,15 \\
\hline 7 & F7 & 4,18 & 2,92 & 0,08 & 0,24 \\
\hline 8 & F8 & 2,51 & 2,32 & 0,05 & 0,12 \\
\hline 9 & F9 & 4,42 & 2,94 & 0,09 & 0,26 \\
\hline 10 & F10 & 4,49 & 3,91 & 0,09 & 0,35 \\
\hline 11 & F11 & 4,53 & 2,81 & 0,09 & 0,25 \\
\hline 12 & F12 & 4,69 & 1,64 & 0,09 & 0,15 \\
\hline \multicolumn{2}{|l|}{ Total Kualitas Pelayan } & 50,64 & 31,99 & 1 & 2,68 \\
\hline \multicolumn{7}{|r|}{ Weighted Total } & & 2,68 \\
\hline \multicolumn{7}{|l|}{ Customer Statisfication Index (Csi) } & 0,54 \\
\hline
\end{tabular}

Tabel 4 jumlah rata - rata penumpang pada jam sibuk

\begin{tabular}{|c|c|c|c|c|}
\hline No & Durasi waktu & Senin & Jum'at & Sabtu \\
\hline 1 & $06.00-07.00$ & 30 & 29 & 31 \\
\hline 2 & $07.00-08.00$ & 36 & 38 & 37 \\
\hline 3 & $08.00-09.00$ & 32 & 33 & 34 \\
\hline 4 & $09.00-10.00$ & 25 & 28 & 27 \\
\hline 5 & $10.00-11.00$ & 23 & 18 & 21 \\
\hline 6 & $11.00-12.00$ & 21 & 22 & 21 \\
\hline 7 & $12.00-13.00$ & 20 & 18 & 22 \\
\hline 8 & $13.00-14.00$ & 22 & 25 & 25 \\
\hline 9 & $14.00-15.00$ & 25 & 26 & 32 \\
\hline 10 & $15.00-16.00$ & 28 & 33 & 36 \\
\hline 11 & $16.00-17.00$ & 30 & 37 & 37 \\
\hline 12 & $17.00-18.00$ & 34 & 39 & 40 \\
\hline \multirow{2}{*}{\multicolumn{2}{|c|}{ Jumlah }} & 326 & 346 & 363 \\
\hline & & \multicolumn{3}{|c|}{1035} \\
\hline \multicolumn{2}{|c|}{ Rata-rata penumpang pada jam sibuk } & \multicolumn{3}{|c|}{345} \\
\hline
\end{tabular}

\subsection{Pembahasan}

Dari hasil pengamatan, survey, dan analisis maka dapat diketahui bahwa:

1. Hasil pengamatan kondisi eksisting fasilitas pelayanan penumpang pada Stasiun Bumiayu dapat dikatakan bahwa beberapa fasilitas belum tersedia dan belum sesuai dengan standar pelayanan minimum yang menyebabkan mengurai kenyamanan penumpang yang ada di stasiun. Beberapa fasilitas pelayanan penumpang yang belum sesuai dengan standar pelayanan minimum diantarannya:

a. Peron 
Peron pada stasiun Bumiayu memiliki panjang sekitar $159 \mathrm{~m}$ (tidak dapat melayani beberapa gerbong dari rangkaian kereta terpanjang), dengan tinggi peron sekitar $43 \mathrm{~cm}$ (peron sedang) sehingga untuk aksesbilitas naik turun penumpang menggunakan bancik

\section{b. Lahan Parkir}

Lahan parkir yang tersedia di stasiun Bumiayu dirasa kurang mencukupi dengan luas kondisi eksisting $1.248 \mathrm{~m}^{2}$, terutama pada jam - jam sibuk dan pada hari libur atau saat arus mudik dan balik. Sehingga banyak kendaraan yang tidak mendapat area untuk parkir. Seringkali harus parkir diluar dan berjalan menuju stasiun Bumiayu. Berikut gambar lahan parkir eksisting dan lahan kosong yang tidak digunakan pada stasiun Bumiayu

\section{c. Kanopi / Over Capping}

Stasiun Bumiayu merupakan stasiun kelas 2 di DAOP 5 Purwokerto, yang sudah melayani kereta kelas eksekutif. Dengan adanya kelas eksekutif tersebut, maka pihak stasiun juga harus memberikan kinerja yang baik bagi para pengguna jasa untuk memberikan pelayanan sesuai dengan kelasnya. Dilihat dari kondisi eksisting kanopi tidak sesuai dengan PM No. 63 Tahun 2019.

2. Dari hasil analisis Importance Performance Analysis Pada TABEL V.1 memiliki nilai rata-rata kinerja (X) sebesar 2,67 dan kepentingan (Y) sebesar 4,25. Sesuai dangan diagram kartesisus dapat diklasifikasikan ke dalam kuadran I (prioritas yang tinggi), yaitu

a. Aksesibilitas naik turun penumpang (F3)

b. Fasilitas Pelayanan Penumpang (F6)

c. Ketersediaan lahan parkir (F12)

Dari hasil diatas dapat diketahui bahwa sebagian besar penumpang di stasiun Bumiayu menginginkan kebutuhan fasilitas kemudahan naik turun penumpang yaitu berupa bancik yang panjang atau dapat berupa peron tinggi (peron yang memiliki elevasi sejajar dengan lantai kereta), fasilitas pelayanan penumpang berupa kanopi/overcapping yang sesuai dengan SPM juga dibutuhkan oleh sebagian besar di Stasiun Bumiayu, dan yang terakhir ada lahan parkir. Fasilitas tersebut juga berguna untuk meningkatkan keselamatan dan kenyamanan penumpang saat naik atau turun dari kereta.

3. Pada analisis Costumer Statisfaction Index Tabel V.3 menunjukkan bahwa penumpang di Stasiun Bumiayu CUKUP PUAS dengan nilai 0,54 yang hampir mencapai index puas pada analisis Costumer Statisfaction Index. Dalam hal ini maka Daerah Operasi 5 Purwokerto diharuskan untuk meningkatkan kinerja pelayanan penumpang agar penumpang merasa nyaman dan puas menggunakan angkutan kereta api.

4. Berdasarkan hasil pengamatan dan pengukuran di lapangan didapatkan panjang peron 2 dan 3 dengan tipe peron pulau (Island Platform) adalah sepanjang $159 \mathrm{~m}$ sedangkan panjang rangkaian terpanjang kereta yang berhenti di Stasiun Bumiayu 238 m (KA Kutojaya Utara Relasi Uap-Pasar Senen) serta panjang jalur efektif masing-masing jalur raya (sepur lurus) sebagai berikut:

a. Jalur II dari $\mathrm{Km} \mathrm{312+493} \mathrm{sampai} \mathrm{dengan}$ $312+971$ dengan panjang jalur efektif 478

b. Jalur III dari $\mathrm{Km} 312+500$ sampai dengan $312+975$ dengan panjang jalur efektif 475

Panjang peron di Stasiun Bumiayu tidak memenuhi standar untuk operasional kereta karena terdapat 1 atau 2 gerbong yang tidakmendapatkan peron maka dibutuhkan perpanjangan peron sekitar $79 \mathrm{~m}$. Berdasarkan Peraturan Menteri Nomor 29 Tahun 2011:

$$
\mathrm{b}=\frac{0,64 \frac{m^{2}}{p n p} \times V \times L F}{\text { panjang rangkainan kereta terpanjang }}
$$

Keterangan:

$\mathrm{b}=$ Lebar peron (meter)

$\mathrm{V}=$ Jumlah rata-rata penumpang per jam sibuk dalam satu tahun (orang) LF $=$ Load Factor $(80 \%)$

$\mathrm{l}=$ Panjang perong sesuai dengan rangkaian terpanjang kereta api penumpang yang beroperasi (meter)

Sehingga lebar peron berdasarkan rumus :

$$
\begin{aligned}
& \mathrm{b}=\frac{0,64 \frac{\mathrm{m}^{2}}{p n p} \times 345 \times 0,8}{238} \\
& \mathrm{~b}=0,7 \mathrm{~m}
\end{aligned}
$$

Pada saat Peak hour lebar peron yang dibutuhkan untuk menampung penumpang adalah $0,7 \mathrm{~m}$

Luas peron eksisting $=$ panjang peron eksisting $\mathrm{x}$ lebar peron eksisting 
$=159 \mathrm{~m} \times 2 \mathrm{~m}=318 \mathrm{~m} 2$

Persyaratan luas peron $=$ lebar peron yang dibutuhkan sebenarnya $\mathrm{x}$ rangkaian kereta terpanjang

$=0,7 \times 238=166,6 \mathrm{~m} 2$

Dengan mengetahui Luas peron eksisting kita mengetahui berapa LOS (Level Of Service) peron yang ada di Stasiun Bumiayu dengan cara sebagai berikut:

$$
\begin{aligned}
\text { LOS } & =\frac{\text { Luas peron eksisting }}{\text { Jumlah pnp pada jam sibuk }} \\
\mid & =\frac{318}{345}=0,92 \mathrm{~m}^{2} / \mathrm{pnp}
\end{aligned}
$$

Dengan perhitungan diatas maka luas peron eksisting masih mencukupi dengan kondisi eksisting, lebar peron 0,7 meter berdasarkan perhitungan PM No.29 Tahun 2011 sedangkan kondisi lebar peron saat ini 2 meter kondisi tersebut masih mencukupi untuk jumlah penumpang tahun 2018. Untuk LOS (Level Of Service) di Stasiun Bumiayu masuk dalam kategori LOS D $(0,9-1,4)$ yang berarti pergerakan penumpang masih longgar. Namun pada peron di Stasiun Bumiayu terdapat masalah terkait dengan panjang peron yang tidak sesuai dengan rangkaian tepanjang yang dilayani serta peron memiliki tinggi $43 \mathrm{~cm}$ dari atas kepala rel (peron sedang).

\section{KESIMPULAN}

Fasilitas pelayanan penumpang eksisting di Stasiun Bumiayu sebagian besar telah memenuhi Standar Pelayanan Minimum sesuai PM No. 63 Tahun 2019. Akan tetapi ada beberapa Fasilitas yang belum memenuhi Standar Pelayanan Minimum dan belum tersedia, yaitu sebagai berikut: Peron, Kanopi/Over Capping, Lahan Parkir Peron, Kanopi/Over Capping, Lahan Parkir menurut penumpang memiliki kinerja yang masih rendah. Pada aksesbilitas naik turun penumpang seperti penggunaan bancik di Stasiun Bumiayu hanya tersedia 9 bancik serta menggunakan peron dengan tinggi $43 \mathrm{~cm}$ (peron sedang). Hal ini menyebabkan tingkat kenyamanan dan keselamatan pada saat proses naik turun penumpang dari dan/atauke kereta. Pada kondisi eksisting kanopi di stasiun Bumiayu belum sesuai dengan PM. No. 63 Tahun 20019, dimana kondisi eksisting hanya menutupi sedikit jalur keluar penumpang. Pada lahan parkir di stasiun Bumiayu dirasa kurang memadai jika terjadi kelonjakan penumpang seperti pada hari raya atau hari libur nasional, maka dari itu diperlukannya pengembangan lahan parkir di stasiun Bumiayu agar semua kendaraan pengguna jasa dapat parkir di dalam atau area stasiun dan tidak mengganggu lalu lintas yang ada di sekitarnya.

Hasil analisis Costumer Statisfaction Index menunjukkan bahwa penumpang di Stasiun Bumiayu pada saat ini merasa CUKUP PUAS terhadap pelayanan yang diberikan dengan nilai 0,54. Dengan bertambahnya jumlah penduduk di Stasiun Bumiayu tiap tahunnya belum tentu tahun berikutnya penumpang akan merasa cukup puas dengan kinerja pelayanan penumpang di Stasiun Bumiayu

\section{REFERENSI}

Harinaldi. (2005). Prinsip-Prinsip Statistik Untuk Teknik dan Sains. Jakarta: Erlangga.

Moenir. (1992). Manajemen Pelayanan Umum di Indonesia.

Peraturan Menteri Perhubungan Nomor 63 Tahun 2019 tentang Standar Pelayanan Minimum. (2019).

Peraturan Pemerintah Nomor 56 Tahun 2009 tentang Penyelenggaraan Perkeretaapian. (2009).

Philip, K. (2003). Manajemen Pemasaran. Jakarta: Gramedia. Tjiptono, F. (2005). Manajemen Pemasaran. Jakarta.

Tjiptono, F. (2012). Pemasaran Strategik. Yogyakarta.

Undang - Undang Nomor 23 Tahun 2007 Tentang Perkeretaapian. (2007). 